\title{
ANALISIS NILAI TAMBAH PENGOLAHAN DAUN KIRINYUH (Chromolaena odorata L.) MENJADI PUPUK ORGANIK CAIR SEBAGAI PUPUK ORGANIK SUMBER DAYA LOKAL
}

\section{Analiysis of Additional Value for Processing Kirinyuh Leaves (Chromolaena odorata L.) into Liquid Organic Fertilizer as Local Resources Organik Fertilizer}

\section{Syarifah Rosmawati}

Fakultas Pertanian Universitas Garut, Jl. Raya Samarang No. 52 A Garut

Email : syarifahrosmawati2@gmail.com

\begin{abstract}
ABSTRAK
Percobaan dilaksanakan di Desa Sindanggalih, Kecamatan Karangtengah, Kabupaten Garut. Waktu percobaan dimulai dari Bulan Maret sampai Juni 2020. Penelitian bertujuan untuk menganalisis nilai tambah pengolahan daun kirinyuh menjadi pupuk organik cair sebagai pupuk organik berbasis sumber daya lokal. Hasil analisis nilai tambah menunjukan proses pengolahan daun kirinyuh menjadi pupuk organik cair pada industri kecil di Desa Sindanggalih Kecamatan Karangtengah Kabupaten Garut terdiri dari pengadaan bahan baku daun kirinyuh dewasa. Proses pengolahan daun kirinyuh menjadi pupuk organik cair meliputi proses pengumpulan daun kirinyuh, pencacahan, fermentasi dan pengemasan. Usaha pengolahan daun kirinyuh menjadi pupuk organik cair pada industri kecil memberikan nilai tambah sebesar Rp 48.400,00 atau sebesar 64,53 persen per proses produksi (rasio tinggi). Industri ini tergolong dalam kategori bernilai tambah tinggi dengan keuntungan sebesar Rp 44.400,00 atau sebesar 91,73 persen.
\end{abstract}

Kata Kunci : Nilai tambah, daun kirinyuh, pengolahan pupuk organik cair.

\begin{abstract}
The experiment was carried out in Sindanggalih Village, Karangtengah District, Garut Regency. The trial period starts from March to June 2020. This research was aimed to analyze the added value of processing kirinyuh leaves into liquid organik fertilizer as organik fertilizer for local resources. The results of the value added analysis show that the processing of kirinyuh leaves into liquid organik fertilizer in Small Industry in Sindanggalih Village, Karangtengah District, Garut Regency consists of the procurement of raw material for mature kirinyuh leaves. The
\end{abstract}


processing of kirinyuh leaves into liquid organik fertilizer includes the process of collecting kirinyuh leaves, chopping, fermentation and packaging. The business of processing kirinyuh leaves into liquid organik fertilizer in small industries provides an added value of $R p .48,400.00$ or 64.53 percent per production process (high ratio). This industry is included in the high value added category with a profit of $R p .44,400.00$ or 91.73 percent.

Keywords: Added value, kirinyuh leaves, liquid organic fertilizer processing.

\section{PENDAHULUAN}

Gulma merupakan tanaman yang tumbuh ditempat yang tidak diinginkan. Kehadiran gulma dapat mengganggu pertumbuhan tanaman yang ada disekitarnya (Sindel dan Coleman, 2010). Kirinyuh (Chromolaena odorata L.) adalah salah satu gulma padang rumput yang sangat merugikan karena dapat mengurangi daya tampung padang penggembalaan dan juga dapat menyebabkan keracunan bahkan kematian pada hewan ternak. Gulma tersebut sering dijumpai dilahan yang kosong dengan pertumbuhan yang lebat dan menggerombol. Gulma kirinyuh diduga memiliki pertahanan yang cukup tinggi karena sangat mudah tumbuh meskipun sudah ditebangi (Thamrin dkk, 2013).

Pengolahan daun kirinyuh menjadi pupuk organik cair merupakan bentuk inovasi dengan adanya penerapan nilai tambah yang diiringi dengan penambahan biaya pengolahan. Produk olahan tersebut memiliki nilai jual yang lebih tinggi sehingga keuntungannya semakin meningkat. Adanya agroindustri yang mendukung nilai tambah produk pertanian sangat bermanfaat dalam peningkatan pendapatan, karena sifat komoditas pertanian yang biasanya mudah rusak dapat terminimalisir dengan adanya pengolahan lebih lanjut. Selain itu, produk olahan ini memiliki nilai jual yang lebih tinggi dibandingkan dengan produk pertanian yang tidak diolah. Kegiatan produksi yang tinggi dengan pengeluaran biaya yang efisien merupakan tujuan pengusaha dalam rangka memperoleh pendapatan yang tinggi (Santosa, 2017).

Produk olahan daun kirinyuh merupakan produk yang belum dikembangkan secara komersial di Kabupaten Garut. Pupuk organik cair daun kirinyuh merupakan salah satu pemanfaatan sumber daya lokal yang dibuat dari daun kirinyuh yang telah difermentasi. Usaha pengolahan pupuk organik cair daun kirinyuh tersebut digerakkan oleh Industri Kecil Kelompok Tani Lampingsari yang beranggotakan petani daerah tersebut dapat menghasilkan pupuk organik cair daun kirinyuh sebanyak 30 liter/bulan dengan netto 1 liter/kemasan botol.

Usaha ini menjadi salah satu kegiatan yang potensial dikembangkan karena dukungan ketersediaan bahan baku di lokasi, kemudahan dalam proses produksi dan adanya potensi pasar. Selain itu, pengolahan pupuk organik cair 
daun kirinyuh merupakan kegiatan potensial yang baik untuk dikembangkan karena dapat meningkatkan pendapatan atau keuntungan bagi petani atau pelaku usaha (Aprilia, 2019; Siburian, 2018; Puspitasari dan Widiyanto, 2015).

Adanya kegiatan industri pengolahan pupuk organik cair daun kirinyuh ini sebagai pupuk organik sumber daya lokal akan memberikan nilai tambah karena dikeluarkannya biaya-biaya selama proses produksi sehingga terbentuk harga baru produk yang lebih tinggi sehingga keuntungannya lebih besar dibandingkan dengan produk tanpa melalui proses pengolahan. Menurut Hermawan (2012), permasalahan yang dihadapi oleh usaha kecil adalah pemasaran, permodalan, bahan baku, pemanfaatan teknologi, manajemen, kemitraan dan kurangnya inovasi produk. Ditinjau dari aspek agroindustri, industri pengolahan pupuk organik cair daun kirinyuh dijalankan dengan teknologi sederhana dan permodalan yang kecil. Hal tersebut menjadi kendala utama dalam upaya pengembangan agroindustri pupuk. Permasalahan lain yang menyebabkan agroindustri ini kurang berkembang yaitu kurangnya inovasi produk antara lain pupuk organik daun kirinyuh masih dijual dalam kemasan curah botol bekas.

Upaya yang dilakukan untuk menghindari kemungkinan industri mengalami kerugian dan mengetahui potensi efisiensi dari usaha yang dijalankan oleh Industri Kecil adalah melakukan suatu analisis nilai tambah produksi pupuk organik cair daun kirinyuh sebagai pupuk organik sumber daya lokal. Hal tersebut dilakukan untuk mengetahui besarnya nilai tambah yang diberikan dari produk pupuk organik cair daun kirinyuh terhadap gulma kirinyuh sebagai bahan baku sehingga bisa diketahui apakah usaha yang dijalankan tersebut efisien dan memberikan keuntungan.

\section{METODE PENELITIAN}

\section{Lokasi dan Waktu Penelitian}

Percobaan dilaksanakan di Desa Sindanggalih, Kecamatan Karangtengah, Kabupaten Garut. Waktu percobaan dimulai dari Bulan Maret sampai Juni 2020. Bahan yang digunakan terdiri atas benih tanaman mentimun Varietas Vanesa, pupuk kotoran ayam yang sudah dikomposkan, pestisida (insektisida), daun kirinyuh, air limbah cucian beras pertama, EM-4, tetes tebu, tanah, dan air. Alat yang digunakan meliputi gayung, timbangan, gelas ukur, beaker glass, saringan, cangkul, sprayer, gunting, ember, penggaris, kamera dan alat tulis.

\section{Metode Analisis}

Metode analisis data adalah deskriftif kuantitatif. Data kuantitatif meliputi perhitungan analisis pendapatan dan keuntungan. Nilai tambah dihitung secara kuantitatif dengan Tabel Hayami. Selain itu, dalam melakukan analisis digunakan alat bantu hitung yaitu microsoft excel. 


\section{Analisis Nilai Tambah}

Analisis nilai tambah metode Hayami (1987) merupakan metode yang memperkirakan perubahan nilai bahan baku setelah mendapatkan perlakuan. Nilai tambah yang terjadi dalam proses pengolahan merupakan selisih dari nilai produk dengan biaya bahan baku dan input lainnya. Prosedur perhitungan nilai tambah pengolahan daun kirinyuh menjadi pupuk organik cair di Desa Sindanggalih Kecamatan Karangtengah Kabupaten Garut dapat ditunjukkan pada Tabel 1.

Tabel 1. Prosedur Perhitungan Nilai Tambah Pengolahan Daun Kirinyuh menjadi Pupuk Organik Cair

\begin{tabular}{clc}
\hline No & \multicolumn{1}{c}{ Uraian } & Cara Perhitungan \\
\hline I. & Output, Input dan Harga & \\
1. & Output/pupuk organik cair $(l /$ proses produksi) & $\mathrm{A}$ \\
2. & Input/Daun kirinyuh $(\mathrm{kg} /$ proses produksi) & $\mathrm{B}$ \\
3. & Tenaga kerja $(\mathrm{HOK} /$ proses produksi) & $\mathrm{C}$ \\
4. & Faktor konversi & $\mathrm{D}=\mathrm{A} / \mathrm{B}$ \\
5. & Koefesien tenaga kerja(HOK/kg) & $\mathrm{E}=\mathrm{C} / \mathrm{B}$ \\
6. & Harga output $(\mathrm{Rp} / \mathrm{l})$ & $\mathrm{F}$ \\
7. & Upah tenaga kerja(Rp/HOK) & $\mathrm{G}$ \\
II. & Pendapatan dan Keuntungan & \\
8. & Harga bahan baku (Rp/kg) & $\mathrm{H}$ \\
9. & Sumbangan input lain $(\mathrm{Rp} / \mathrm{kg})$ & $\mathrm{I}$ \\
10. & Nilai Output $(\mathrm{Rp})$ & $\mathrm{J}=\mathrm{D} \times \mathrm{F}$ \\
11. & a. Nilai tambah (Rp/kg) & $\mathrm{K}=\mathrm{J}-\mathrm{H}-\mathrm{I}$ \\
& b. Rasio Nilai Tambah $(\%)$ & $\mathrm{L}=(\mathrm{K} / \mathrm{J}) \times 100$ \\
12. & Imbalan tenaga kerja $(\mathrm{Rp} / \mathrm{kg})$ & $\mathrm{M}=\mathrm{E} \times \mathrm{G}$ \\
13. & a. Keuntungan $(\mathrm{Rp} / \mathrm{kg})$ & $\mathrm{N}=\mathrm{K}-\mathrm{M}$ \\
& b. Tingkat keuntungan $(\%)$ & $\mathrm{O}=(\mathrm{N} / \mathrm{K}) \times 100$ \\
\hline
\end{tabular}

Sumber : Hayami et al. (1987) dan Mubarok et al. (2015)

Keterangan :

1. Nilai tambah menunjukkan selisih antara nilai output dengan bahan baku utama dan sumbangan input lain, tidak termasuk tenaga kerja.

2. Rasio nilai tambah menunjukkan persentase nilai tambah dari nilai output (nilai produk).

3. Keuntungan menunjukkan bagian yang diterima industri pengolahan.

4. Tingkat keuntungan menunjukkan persentase keuntungan dari nilai tambah.

5. HOK : Hari Orang Kerja

\section{HASIL DAN PEMBAHASAN}

\section{Proses Pembuatan Pupuk Organik Cair}

Pembuatan pupuk organik cair daun kirinyuh pada penelitian ini dilakukan menurut Sado (2016) yaitu: Sediakan air (20 liter), air cucian beras 
pertama (4 liter), tetes tebu (1 liter), EM-4 (1 liter). Daun kirinyuh (dewasa) sebanyak $10 \mathrm{~kg}$, dicacah kemudian dimasukkan ke dalam wadah. Semua bahan diaduk sampai merata, ditutup dan difermentasikan sesuai dengan perlakuan lama fermentasi. Selama fermentasi setiap 1 hari sekali wadah penampung dibuka, larutan POC kirinyuh kemudian diaduk kembali hingga merata sampai hilang gasnya. Setelah selesai difermentasikan, saringlah POC daun kirinyuh.

\section{Nilai Tambah Usaha Pupuk Organik Cair}

Nilai tambah (value added) adalah pertambahan nilai suatu produk atau komoditas karena mengalami proses pengolahan, pengangkutan, ataupun penyimpanan dalam suatu produksi. Proses pengolahan nilai tambah dapat didefinisikan sebagai selisih antara nilai produk dengan nilai bahan baku dan input lainnya, tidak termasuk tenaga kerja (Hayami et al., 1987). Perhitungan analisis nilai tambah pengolahan daun kirinyuh menjadi pupuk organik cair ditunjukkan pada Tabel 2.

Tabel 2. Analisis Nilai Tambah Pengolahan Daun Kirinyuh menjadi Pupuk Organik Cair pada Industri Kecil

\begin{tabular}{|c|c|c|}
\hline No & Uraian & Hasil Perhitungan \\
\hline I. & Output, Input dan Harga & \\
\hline 1. & Output/pupuk organik cair ( $l$ /proses produksi) & 30 \\
\hline 2. & Input/Daun kirinyuh (kg/proses produksi) & 10 \\
\hline 3. & Tenaga kerja (HOK/proses produksi) & 1 \\
\hline 4. & Faktor konversi & 3 \\
\hline 5. & Koefesien tenaga kerja $(\mathrm{HOK} / \mathrm{kg})$ & 0,1 \\
\hline 6. & Harga output $(\operatorname{Rp} / l)$ & 25.000 \\
\hline 7. & Upah tenaga kerja(Rp/HOK) & 40.000 \\
\hline II. & Pendapatan dan Keuntungan & \\
\hline 8. & Harga bahan baku (Rp/kg) & 20.000 \\
\hline 9. & Sumbangan input lain $(\mathrm{Rp} / \mathrm{kg})$ & 6.600 \\
\hline 10. & Nilai Output (Rp) & 75.000 \\
\hline \multirow[t]{2}{*}{11.} & a. Nilai tambah $(\mathrm{Rp} / \mathrm{kg})$ & 48.400 \\
\hline & b. Rasio Nilai Tambah (\%) & 64,53 \\
\hline 12. & Imbalan tenaga kerja $(\mathrm{Rp} / \mathrm{kg})$ & 4.000 \\
\hline \multirow[t]{2}{*}{13.} & a. Keuntungan $(\mathrm{Rp} / \mathrm{kg})$ & 44.400 \\
\hline & b. Tingkat keuntungan (\%) & 91,73 \\
\hline
\end{tabular}

Sumber : Data primer diolah (2020)

Bahan baku yang digunakan dalam proses pembuatan pupuk organik cair pada industri kecil adalah daun kirinyuh dewasa yang diukur dalam satuan kilogram (kg). Hasil perhitungan nilai tambah (Tabel 2), diketahui bahwa untuk satu kali proses produksi pupuk organik cair menggunakan bahan baku (input) sebesar $10 \mathrm{~kg}$ akan menghasilkan pupuk organik cair (output) sebesar 30 liter. 
Harga bahan baku (daun kirinyuh) adalah sebesar Rp 0/kg. Kebutuhan tenaga kerja dalam satu kali proses produksi kelanting adalah 1 HOK. Tenaga kerja dalam proses pengolahan daun kirinyuh menjadi pupuk organik cair dilakukan oleh tenaga kerja anggota kelompok tani. Besarnya koefisien tenaga kerja menunjukkan besarnya sumbangan tenaga.

Tenaga kerja yang dibutuhkan untuk mengolah $10 \mathrm{~kg}$ daun kirinyuh menjadi pupuk organik cair. Nilai koefisien tenaga kerja juga menunjukkan apakah industri tersebut sudah efisien dalam berproduksi atau sebaliknya. Ratarata nilai koefisien tenaga kerja pada pengolahan daun kirinyuh menjadi pupuk organik cair adalah sebesar 0,1. Hal ini menunjukkan bahwa untuk mengolah 10 $\mathrm{kg}$ daun kirinyuh menjadi 30 liter pupuk organik cair dibutuhkan tenaga $1 \mathrm{HOK}$ (hari orang kerja). Semakin kecil nilai koefisien tenaga kerja maka semakin efisien industri tersebut menjalankan usahanya atau berproduksi. Nilai faktor konversi merupakan perbandingan antara output dengan input.

Nilai faktor konversi pada pengolahan daun kirinyuh menjadi pupuk organik cair diperoleh dari perhitungan jumlah output (pupuk organik cair) dibagi dengan jumlah input (daun kirinyuh) yang digunakan. Nilai faktor konversi untuk pupuk organik cair adalah sebesar 3. Nilai faktor konversi menunjukkan bahwa setiap $10 \mathrm{~kg}$ daun kirinyuh mampu menghasilkan 30 liter pupuk organik cair. Nilai faktor konversi merupakan perbandingan antara output dengan input. Nilai faktor konversi pada pengolahan daun kirinyuh menjadi pupuk organik cair diperoleh dari perhitungan jumlah output (pupuk organik cair) dibagi dengan jumlah input (daun kirinyuh) yang digunakan. Nilai faktor konversi untuk pupuk organik cair adalah sebesar 3. Nilai faktor konversi menunjukkan bahwa setiap $10 \mathrm{~kg}$ daun kirinyuh mampu menghasilkan 30 liter pupuk organik cair.

Tabel 3. Upah Tenaga Kerja pada Proses Pengolahan Daun Kirinyuh menjadi Pupuk Organik Cair pada Industri Kecil

\begin{tabular}{|c|c|c|c|c|c|}
\hline No & Pekerjaan & $\begin{array}{c}\text { Jumlah } \\
\text { Tenaga } \\
\text { Kerja } \\
\text { (orang) }\end{array}$ & $\begin{array}{c}\text { Upah } \\
\text { (Rp/orang) }\end{array}$ & $\begin{array}{c}\text { Jumlah } \\
\text { Hari }\end{array}$ & Total (Rp) \\
\hline 1. & $\begin{array}{l}\text { Mengumpulkan daun } \\
\text { kirinyuh, mencacah dan } \\
\text { mengemas }\end{array}$ & 1 & $40.000,00$ & 2 & $80.000,00$ \\
\hline Tota & & 1 & & & $80.000,00$ \\
\hline Rata & -rata & & & & $80.000,00$ \\
\hline
\end{tabular}

Sumber : Data primer diolah (2020)

Upah tenaga kerja pada proses pengolahan daun kirinyuh menjadi pupuk organik cair pada Industri Kecil adalah sebesar Rp $40.000,00 / \mathrm{HOK} /$ proses produksi. Rata-rata upah tenaga kerja dihitung dari 
jumlah upah untuk satu kali proses produksi dibagi dengan jumlah tenaga kerja dengan pembayaran upah sebesar Rp 40.00,00/hari. Upah tenaga kerja pada proses pengolahan daun kirinyuh menjadi pupuk organik cair pada Industri Kecil ditunjukkan pada Tabel 3.

Harga jual pupuk organik cair (output) pada Industri Kecil di Desa Sindanggalih Kecamatan Karangtengah Kabupaten Garut adalah sebesar Rp750.000,00/ember besar dimana satu ember adalah 30 liter pupuk organik cair sehingga apabila dihitung rata-rata harga jualnya adalah sebesar Rp25.000,00/kg. Penentuan harga jual pupuk organik cair tentu tidak terlepas dari perhitungan biaya produksi yang dikeluarkan untuk mengolah daun kirinyuh menjadi pupuk organik cair.

Besarnya biaya produksi akan mempengaruhi besarnya harga jual pupuk organik cair dan tingkat keuntungan yang akan diperoleh. Apabila harga jual produk lebih besar dari biaya produksi maka usaha tersebut akan memperoleh keuntungan dan sebaliknya apabila harga jual produk lebih kecil dari biaya produksi maka usaha tersebut mengalami kerugian dan apabila harga jual sama besarnya dengan dengan harga output maka usaha tersebut dalam kondisi tidak untung dan tidak rugi (impas).

Sumbangan input lain untuk pengolahan daun kirinyuh menjadi pupuk organik cair pada Industri Kecil antara lain EM-4, Molasses dan limbah air cucian beras. Perhitungan sumbangan input lain adalah perbandingan total sumbangan input lain dibagi dengan jumlah bahan baku yang digunakan. Rata-rata sumbangan input lain untuk pengolahan daun kirinyuh menjadi pupuk organik cair pada Industri Kecil adalah Rp46.00 per produksi yang diperoleh dari hasil bagi jumlah total sumbangan input lain sebesar Rp66.000,00 dengan jumlah bahan baku daun kirinyuh sebesar $10 \mathrm{~kg}$. Rata-rata total sumbangan input lain untuk pengolahan daun kirinyuh menjadi pupuk organik cair pada Industri Kecil ditunjukkan pada Tabel 4.

Tabel 4. Rata-rata Sumbangan Input Lain pada Proses Pengolahan Daun Kirinyuh menjadi Pupuk Organik Cair pada Industri Kecil

\begin{tabular}{llrrrr}
\hline No & \multicolumn{1}{c}{ Bahan } & Kuantitas & Satuan & Harga (Rp) & Jumlah Harga (Rp) \\
\hline 1. & Air limbah cucian & 4 & Liter & 0 & 0 \\
& beras & & & & \\
2. & EM-4 & 1 & Liter & $25.000,00$ & $25.000,00$ \\
3. Tetes Tebu & 1 & Liter & $36.000,00$ & $36.000,00$ \\
$4 . \quad$ Air & 20 & Liter & $5.000,00$ & $5.000,00$ \\
\hline \multicolumn{7}{l}{ Total } \\
\hline \multicolumn{7}{l}{ Rata-rata (per kg daun kirinyuh yang digunakan) } \\
\hline
\end{tabular}

Sumber : Data primer (2020)

Perhitungan nilai tambah bertujuan untuk mengetahui besarnya nilai tambah yang diberikan oleh satu liter pupuk organik cair terhadap bahan baku 
daun kirinyuh yang digunakan. Besarnya nilai tambah tergantung pada biaya yang dikeluarkan meliputi biaya pembelian bahan baku dan sumbangan input lain tanpa upah tenaga kerja. Nilai tambah dari pengolahan daun kirinyuh menjadi pupuk organik cair pada Industri Kecil adalah sebesar Rp 48.400,00/liter. Rasio nilai tambah yaitu perbandingan antara nilai tambah dengan nilai output. Rasio nilai tambah daun kirinyuh per proses produksi pada pengolahan pupuk organik cair adalah sebesar 64,53 persen. Keuntungan yang diperoleh dari pembuatan pupuk organik cair ini adalah sebesar Rp 44.400,00 atau 91,73 persen dari nilai tambah produk.

Nilai tambah pengolahan daun kirinyuh menjadi pupuk organik cair pada Industri Kecil lebih besar dari pada nilai tambah dan rasio nilai tambah dari pengolahan daun kirinyuh segar. Hal ini menunjukkan bahwa usaha pengolahan daun kirinyuh menjadi pupuk organik cair pada Industri Kecil tergolong dalam kategori bernilai tambah tinggi (rasio lebih 40 persen). Menurut Hayami (1987), kategori nilai tambah ditentukan dengan kriteria hasil yaitu rasio kurang 15 persen artinya nilai tambah rendah, nilai rasio berkisar antara 15-40 persen termasuk nilai tambah sedang dan nilai rasio lebih 40 persen artinya nilai tambah tinggi.

Proses pengolahan daun kirinyuh menjadi pupuk organik cair pada Industri Kecil memiliki potensi yang baik untuk terus dikembangkan karena memberikan nilai tambah dan keuntungan yang tinggi. Hal ini tentunya tidak terlepas dari dukungan ketersediaan bahan baku dan pemasaran. Bahan baku yang diperoleh pada proses pembuatan pupuk organik cair diperoleh dari lahan yang kosong (tidak produktif) sehingga memudahkan berlangsungnya proses produksi dan harganya relatif terjangkau dibandingkan dengan bahan baku yang dibeli dipasar (harga relatif lebih mahal). Perubahan harga baku tentunya akan mempengaruhi nilai tambah dan keuntungan yang diperoleh industri.

Industri pengolahan daun kirinyuh menjadi pupuk organik cair akan tetap bertahan dan memberikan nilai tambah dan keuntungan yang rendah pada kondisi bahan baku membeli membuat perubahan harga daun kirinyuh sebesar Rp 5.000,00/kg (Tabel 5). Apabila harga bahan baku lebih besar dari Rp $5.000,00 / \mathrm{kg}$ maka usaha tersebut akan mengalami kerugian karena hasil penjualan tidak dapat menutupi biaya yang dikeluarkan untuk proses produksi. Biaya produksi merupakan jumlah biaya yang dikeluarkan untuk membiayai proses produksi yang meliputi biaya tetap dan biaya variabel. Biaya tetap pada proses pengolahan daun kirinyuh menjadi pupuk organik cair terdiri dari biaya penyusutan peralatan yang digunakan dalam produksi pupuk organik cair, sedangkan biaya variabel terdiri dari biaya bahan baku, biaya sumbangan input lain dan upah tenaga kerja. Besarnya biaya produksi pupuk organik cair pada Industri Kecil di Desa Sindanggalih Kecamatan Karangtengah Kabupaten Garut disajikan pada Tabel 6. 
Tabel 5. Nilai Tambah Proses Pengolahan Daun Kirinyuh menjadi Pupuk Organik Cair pada Industri Kecil

\begin{tabular}{crrrrr}
\hline No & $\begin{array}{c}\text { Harga bahan } \\
\text { baku (Rp/kg) }\end{array}$ & $\begin{array}{c}\text { Nilai } \\
\text { tambah (Rp) }\end{array}$ & $\begin{array}{c}\text { Rasio nilai } \\
\text { tambah } \\
\mathbf{( \% )}\end{array}$ & $\begin{array}{c}\text { Keuntungan } \\
\mathbf{( R p )}\end{array}$ & \multicolumn{1}{c}{$\begin{array}{c}\text { Tingkat } \\
\text { keuntungan (\%) }\end{array}$} \\
\hline 1. & $20.000,00$ & $48.400,00$ & 64,53 & $44.400,00$ & 91,73 \\
2. & 0 & 0 & 0 & 0 & 0 \\
3. & $25.000,00$ & $43.400,00$ & 57,87 & $39.400,00$ & 90,78 \\
4. & $36.000,00$ & $32.400,00$ & 43,2 & $28.400,00$ & 87,65 \\
5. & 5000,00 & $63.400,00$ & 84,53 & $59.400,00$ & 93,69 \\
\hline
\end{tabular}

Total biaya produksi pada pengolahan daun kirinyuh menjadi pupuk organik cair pada Industri Kecil adalah sebesar Rp 456.000,00 per bulan per proses produksi (Tabel 6). Penerimaan adalah pendapatan yang diperoleh pengolah pupuk organik cair yaitu jumlah produksi pupuk organik cair yang dihasilkan dikalikan dengan harga yang berlaku yang diukur dalam satuan rupiah (Rp). Besarnya penerimaan usaha pengolahan pupuk organik cair pada Industri ini adalah sebesar Rp 7.50.000,00 per proses produksi. Hasil perhitungan tersebut diperoleh dari harga jual pupuk organik cair sebesar Rp 25.000,00/liter dikalikan dengan jumlah output sebesar 30 liter jual pupuk organik cair setiap proses produksinya.

Tabel 6. Biaya Produksi Pengolahan Daun Kirinyuh menjadi Pupuk Organik Cair pada Industri Kecil KT Lampingsari

\begin{tabular}{lrr}
\hline No & \multicolumn{1}{c}{ Uraian } & Nilai (Rp) \\
\hline 1. & Biaya alat & \\
$\quad$ a. Penyusutan alat & $2.30 .000,00$ \\
2. Biaya variabel & \\
$\quad$ a. Bahan baku & $80.000,00$ \\
b. Sumbangan input lain & $66.000,00$ \\
c. Upah tenaga kerja & $80.000,00$ \\
\hline Total Biaya Produksi & $456.000,00$
\end{tabular}

Sumber : Data primer (2020)

\section{KESIMPULAN}

Proses pengolahan daun kirinyuh menjadi pupuk organik cair pada Industri Kecil di Desa Sindanggalih Kecamatan Karangtengah Kabupaten Garut terdiri dari pengadaan bahan baku daun kirinyuh dewasa. Proses pengolahan daun kirinyuh menjadi pupuk organik cair meliputi proses pengumpulan daun kirinyuh, pencacahan, fermentasi dan pengemasan. Usaha pengolahan daun kirinyuh menjadi pupuk organik cair pada Industri Kecil memberikan nilai tambah sebesar Rp 48.400,00 atau sebesar 64,53 persen per proses produksi (rasio 
tinggi). Industri ini tergolong dalam kategori bernilai tambah tinggi dengan keuntungan sebesar Rp 44.400,00 atau sebesar 91,73 persen.

\section{IMPLIKASI KEBIJAKAN}

Usaha ini diharapkan dapat mengembangkan produk olahannya menjadi produk olahan yang siap pakai oleh konsumen dan memperbaiki kemasan dari produk olahan tersebut serta untuk memperluas pemasaran dari produk. Usaha olahan daun kirinyuh memiliki potensi untuk dikembangkan tetapi pengetahuan dan keterbatasan modal menjadi kendala dalam mengembangkan usaha ini. Oleh karena itu, perlunya perluasan informasi tentang produk olahan yang berbahan daun kirinyuh dan bantuan permodalan dalam rangka meningkatkan kualitas hasil produk olahan daun kirinyuh khususnya pupuk organik cair.

\section{UCAPAN TERIMAKASIH}

Penulis menyampaikan terimakasih kepada pembimbing yang telah membimbing sehingga dapat menyelesaikan penelitian ini.

\section{DAFTAR PUSTAKA}

Aprilia, N. 2019. “Analisis Rantai Pasok dan Nilai Tambah Agorindustri Kelanting di Desa Gantimulyo Kecamatan Pekalongan Kabupaten Lampung Timur". Skripsi. Universitas Lampung, Bandar Lampung.

Hayami, Y. 1987. Agricultural Marketing and Processing in Upland Java, A Perspective From Sunda Village. Coarse Grains Pulses Roots and Tuber Center (CGPRTC). Bogor. $75 \mathrm{hlm}$.

Hermawan, A. 2012. Komunikasi Pemasaran. Penerbit Erlangga, Jakarta.

Puspitasari, A.T., dan Widiyanto. 2015. Strategi pengembangan industri kecil lanting di Kabupaten Kebumen. Jurnal Pendidikan Ekonomi Dinamika Pendidikan, 10 (2): 117-135.

Sado. 2016. Pengaruh pemberian pupuk cair daun gamal (Gliricidia sepium) terhadap pertubuhan tanaman sawi caisim (Brassica juncea L.) Skripsi. Universitas Sanata Dharma Yogyakarta.

Santosa, R. 2017. Kelayakan finansial dan nilai tambah usaha agroindustri keripik ubi kayu di Kecamatan Saronggi, Kabupaten Sumenep. Jurnal Pertanian Cemara, 1 (14): 21-34.

Siburian, R.V. 2018. Analisis efisiensi pemasaran agroindustri klanting di Kecamatan Negeri Katon Kabupaten Pesawaran. Jurnal Ilmu Ilmu Agribisnis, 4 (4): 131-135. 
Sindel, B., \& Coleman, M. 2010. Weed Detection and Control on Small Farms. Australia Government, Australia.

Thamrin M, S. Asikin, M. Willis. 2013. Tumbuhan Kirinyu Chromolaena Odorata (L) (Asteraceae: Asterales) Sebagai Insektisida Nabati Untuk Mengendalikan Ulat Grayak Spodoptera Litura. Jurnal Penelitian dan Pengembangan Pertanian 32(3): 112-121. 